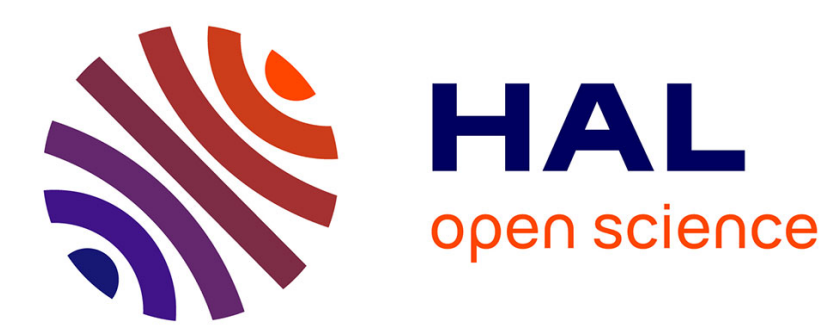

\title{
The late-Holocene tufa decline in Europe: Myth or reality?
}

Julie Dabkowski

\section{To cite this version:}

Julie Dabkowski. The late-Holocene tufa decline in Europe: Myth or reality? Quaternary Science Reviews, 2020, 230, pp.106141. 10.1016/j.quascirev.2019.106141 . hal-02434361

\section{HAL Id: hal-02434361 \\ https://hal.science/hal-02434361}

Submitted on 23 Nov 2020

HAL is a multi-disciplinary open access archive for the deposit and dissemination of scientific research documents, whether they are published or not. The documents may come from teaching and research institutions in France or abroad, or from public or private research centers.
L'archive ouverte pluridisciplinaire HAL, est destinée au dépôt et à la diffusion de documents scientifiques de niveau recherche, publiés ou non, émanant des établissements d'enseignement et de recherche français ou étrangers, des laboratoires publics ou privés. 


\title{
The late-Holocene tufa decline in Europe: Myth or reality?
}

\author{
Julie Dabkowski
}

CNRS, Laboratoire de Géographie Physique: environnements quaternaires et actuels - UMR 8591 (CNRS, Université Paris 1 Panthéon-Sorbonne, UPEC), 92195 Meudon Cedex, France

\section{A R T I C L E I N F O}

\section{Article history:}

Received 12 August 2019

Received in revised form 13 December 2019

Accepted 20 December 2019

Available online $\mathrm{xxx}$

\section{Keywords:}

Calcareous tufa

Holocene

Climate change

Human impact

Deforestation

Europe

\begin{abstract}
A B S T R A C T
In 1993, Goudie and co-authors named the postulate that there would be a marked decline in the deposition of calcareous tufa in Europe since ca. 2500 BP 'the late-Holocene tufa decline'. However, the growing development of investigation on calcareous tufas and considerable improvement in dating methods, especially radiocarbon dating, has provided reliable evidence of deposits developing until our present days. I thus discuss the reality of the decline, reviewing 62 tufa sites in Europe and their time distribution based both on radiocarbon dates and biochronological data and distinguishing different cases depending on tufa size and types. I demonstrate that the late-Holocene tufa decline is actually a general view of a rather complex tendency: after a maximum during the Atlantic period, fluvial tufas are systematically affected by a decline from ca. $5 \mathrm{ka}$ cal. BP but no general trend is shown in the development of proximal (spring-fed) or lacustrine tufas. This observation is likely to result from the increasing impact of human activity (mainly deforestation) on landscapes, and more specifically on fluvial environments, from the Bronze Age.
\end{abstract}

(C) 2020 Elsevier Ltd. All rights reserved.

\section{Introduction}

In the last decades, the growing number of scientific publications on calcareous tufas has demonstrated their relevance as archives of interglacial palaeoenvironments and palaeoclimates (e.g. (Andrews, 2006; Antoine et al., 2007; Dabkowski et al., 2011; Limondin-Lozouet and Preece, 2014; Ortiz et al., 2009; Pazzaglia et al., 2013; Ricci et al., 2015). Tufas are indeed one of the few continental archives capable of building true synergistic records of past environments (including physical, faunal and floral changes) that simultaneously provide independent records of regional climatic changes (especially from calcite stable isotopes), and that can be dated precisely and objectively (Capezzuoli et al., 2014; Dabkowski, 2014). To date, most investigations have been focusing on Holocene deposits as they are more numerous and better preserved than older tufas (Ford and Pedley, 1996; Pentecost, 1995). For this recent period, their distribution and development have long been discussed as a promising indicator of anthropisation because, as any fluvial systems, tufas are highly responsive to environmental changes, especially those induced by human activity (Antoine et al., 2002; Pastre et al., 2001).

In 1993, Goudie and co-authors named the postulate that there

E-mail address: julie.dabkowski@lgp.cnrs.fr. would be a marked decline in the deposition of calcareous tufa in Europe since ca. 2500 BP 'the late-Holocene tufa decline'. The concept got a certain success in the community of researchers working on travertines and tufas then, this paper has been extensively and regularly cited (104 citations according to Scopus database, October 2019) while its main topic is actually not to demonstrate the existence of such a decline but to discuss the role of various natural and anthropogenic changes that may have affected tufas. The authors themselves wrote: 'In many parts of Europe there appears to be evidence for a decline in tufa deposition rates since the mid-Holocene. However, the veracity of this trend needs to be investigated further' (Goudie et al., 1993, p. 185). Nevertheless, the 'late-Holocene tufa decline' rapidly became a paradigm (e.g. (Andrews et al., 1994; Pentecost, 1995; Pentecost, 2005; Žák et al., 2002) then, most discussions have concentrated on its causes and mechanisms (Dramis et al., 1999; Pedley, 2009; Vaudour, 1994) or, in the case of long Holocene sequences including recent to modern tufa depositions, on the reasons justifying the absence of such a decline (e.g. (Dabkowski et al., 2015).

The late-Holocene tufa decline was rapidly debated after the publication by Goudie et al. (1993). Baker and Simms (1998) thus demonstrated that 'there has been a considerable underreporting of active tufa deposition' and that 'this observation, in turn, suggests that the same has occurred for fossil sites'. In the last decades, the growing development of investigations on calcareous tufas in 
Europe and considerable improvements in dating methods, especially radiocarbon dating, have provided reliable evidence of deposits developing until our present days (Andrews et al., 2000; Dabkowski et al., 2015; Dobrowolski et al., 2002, 2005; Hájek et al., 2016; Ložek, 2009; Pedley et al., 1996; Srdoč et al., 1980). All these publications also illustrate a large diversity in tufa deposits.

A large part of the literature on Holocene European tufas is here reviewed, including past to recent publications, with the aim to better constrain the reality of the decline and distinguished different cases depending on tufa size, types or geomorphological settings.

\section{Time distribution of tufa deposits during the Holocene: the state of the art}

The chronological distribution of tufas over the Holocene has been discussed since the 1960s, then more intensively during the 1970s and 1980s while radiocarbon dating became increasingly available for these deposits. At regional scales, observations suggesting a maximal development of tufas during the Atlantic period, in terms of deposition rate and/or frequency, were made in Southern France, Central Europe, Britain, Northern Spain, Germany, etc. (Ambert, 1981; Bögli, 1980; Evans, 1972; González-Pellejero, 1986; Stirn, 1964; Weisrock, 1986). The first review of dated sites over Europe (also including Morocco and Israel) was provided by Jean Vaudour (1986a), including about 30 locations or groups of locations (i.e. from the same region/country). Chronological data used for this early review were provided by both biostratigraphy and, when available, radiocarbon or $\mathrm{U} / \mathrm{Th}$ dating. They highlighted a decrease in tufa deposition during the Subboreal period up to an apparent stop in their accumulation at the Subboreal-Subatlantic transition (Vaudour, 1986a); pattern which was thus defined as the 'late-Holocene tufa decline' by Goudie et al. (1993). Following these early publications, several regional inventories were published during the last decades (Alexandrowicz et al., 2016; Nicod, 2010; Ollivier et al., 2006; Starkel et al., 2013; Vaudour, 1994).

Parallel, with the development of radiocarbon dating on tufa calcite and associated organic matter (Dobrowolski et al., 2002, 2005; Pazdur and Pazdur, 1986, 1990; Srdoč et al., 1980; Thorpe et al., 1980), a few, intensively cited, reviews have focused on the frequency of dates per time interval (of a thousand years) at regional to European scale (Pentecost, 1993, 1995): they showed a strong predominance of dates between 7 and 9 ka. However, in some of these reviews, data collected from thermogene travertines are including (Pentecost, 1995, 2005), while their accumulation processes are very different from those of (meteogene) calcareous tufas and usually independent of environmental or climatic parameters (Capezzuoli et al., 2014).

Generally, little is said about the type of tufa deposits and the stratigraphic context of sampling for dating and/or associated palaeoenvironmental studies that provide biochronological information. However, Baker and Simms (1998) suggested that the record of the Late-Holocene decline might depend on the type of tufa: in Wessex (UK), they distinguish large deposits $\left(>1000 \mathrm{~m}^{2}\right)$ affected by a decline while smaller sites are not. Later, Ollivier et al. (2006) stressed that the geomorphological context of tufas from Southeastern France is highly important to assess the chronological significance of a sequence: e.g. as tufas are affected by a lateral transgression within the valley, several profiles might be stacked to cover the whole duration of the tufa deposition. Alexandrowicz et al. (2016) also discussed the chronological distribution of tufas in the Pieniny Mountains (Carpathians, Poland) according to their morphology and place of deposition, while in the Lublin upland (Eastern Poland), Dobrowolski et al. (2002) attempted to correlate tufa granulometry and sedimentation rate with Holocene temperature changes. To test these assumptions on a tufa decline and involved mechanisms at the European scale, a new review of calcareous tufas and their time distribution over the Holocene appears necessary.

\section{Tufa deposition in Europe during the Holocene: a new review}

Data collected from 79 references (journal articles, previous reviews, books, technical reports, etc.; Table 1) on a total of 66 individual locations have been summarised in Fig. 1. Fourteen countries are represented, covering Europe from Northern UK (Scotland) to Southern Spain and Italy and from the French West coast (Normandy) to Eastern Poland (Lublin Upland) and Belarus (Table 1).

For the purpose of this paper, only publications with strong chronological information (from radiometric dating or biostratigraphy) were considered. Most of them are related to palaeoenvironmental reconstructions, which is actually the main field of investigation regarding fossil tufa deposits (Dabkowski, 2014; Pentecost, 1995). The most common proxies are molluscs and pollen. In some cases, plant macrofossils are also found, and more rarely ostracods. At some sites, archaeological artefacts (ceramics, hearths, slags, etc.) also give chronological indications (Fig. 1).

\subsection{Time distribution of radiocarbon dates in tufa deposits}

To allow comparisons between dates obtained from the 1980s to nowadays and, with previous reviews of Holocene tufa dating (Pentecost, 1993, 1995, 2005), uncalibrated dates are considered in this section. The number of dates per sites is highly variable. The tufas from Plitvice and Krka (Croatia) are exceptionally well dated, which reflects the extensive work of the Zagreb dating researcher group and its collaborators over decades (Horvatinčić et al., 2000; Roglic, 1977; Srdoč et al., 1980, 1985, 1994). These two Croatian locations provide almost as many dates (212; Figs. 1 and 2) as all the other 48 dated sites together (234 dates). They are thus excluded from the following discussion on the distribution of radiocarbon dates as they may induce an over-representation of the Late Holocene in the corpus of data (Fig. 2). More commonly, dated tufa sites provide 1 to 10 dates (4.7 dates in average; Fig. 1 ) rarely more, except at recently studied sites (Dabkowski et al., 2015; Hájek et al., 2016; Pazdur et al., 2002): in the last decades, high-quality radiometric dating became mandatory for publication in international journals while technical and methodological progress allowed to date new and smaller amount of material.

While the occurrence of a Late Holocene tufa decline was previously demonstrated by the greatest number of dates ranging between 7 and 9 ka BP (Pentecost, 1993, 1995, 2005), newly reviewed data does not show such a strong tendency (Fig. 3). Maximal frequencies of dates are reached at 6-7 and 8-9 ka BP (respectively 36 and 34 dates), then at 5-6 and 9-10 ka BP (31 dates for both intervals), while more than 23 dates are still inventoried at 3-4 ka BP (Fig. 1). Conversely, the 7-8 ka-interval provides fewer dates (15). These observations are likely to reflect the availability of material to be dated in tufas. While the opportunity for dates was long depending on the presence of well-preserved organic matter (as organic sediment accumulation or large charcoals and plant macrofossils), often limited to some stratigraphic units, the development of dating on calcite (or smaller amount of organic matter) and more recently on mollusc shells has resulted in the increase of dates and their better distribution over tufa sequences (Ollivier et al., 2006). The sites where only organic material was dated thus provide fewer dates (Fig. 1). A strong discrepancy between the number of dates and the number of actually dated sites is also observed (Fig. 3). Between 5 and 9ka BP, dated sites 
Table 1

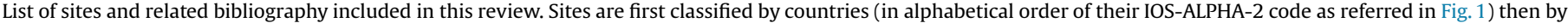
alphabetical order of the site main name.




Table 1 (continued)

\begin{tabular}{|c|c|}
\hline Trzebienice & Pazdur et al. (1988) \\
\hline Tylka & Alexandrowicz (2013)/Alexandrowicz et al. (2016) \\
\hline Zawadówka & Dobrowolski et al. (2005) \\
\hline \multicolumn{2}{|c|}{ SK: SLOVAKIA } \\
\hline Háj & Gradziński et al. (2013) \\
\hline Hrhov & Gradziński et al. (2013) \\
\hline Mituchovci & Hájek et al. (2016)/Dabkowski et al. (2018) \\
\hline
\end{tabular}

provide up to seven dates per 1 ka-interval ( 2 dates on average; Fig. 1). Consequently, the apparent highest date frequency at this time corresponds to around 20 sites only. Actually, when considering dated sites (instead of dates), no tendency is seen: the number of dated sites remains around 15-20 during the Early and Middle Holocene and only slightly lowers to $7-8$ per $1 \mathrm{ka}$-interval from $3 \mathrm{ka}$ BP to present time (Fig. 3).

Additionally, the absence of date does obviously not indicate the absence of tufa deposition: in this review, almost a quarter of the inventoried sites are not dated by radiocarbon (Fig. 1), including long sequences such as Ethe in Belgium (Gueurts, 1976) or Okono and Teklits in Belarus (Makhnach et al., 2004). Similarly, at sites showing a single or few dates, these are unlikely to be representative of the full period of time covered by the tufa sequence. The stratigraphic position of dated samples within the whole tufa deposit should be carefully considered which in turn also prevent to include dates which are not consistent with other chronological information (due to e.g. reworked material, diagenesis, dead carbon ageing; (Pazdur and Pazdur, 1990; Pazdur et al., 1988).

Therefore, considering these numerous biases, the frequencies of dates or dated sites are not suitable for discussing the time distribution of tufas over the Holocene. This review thus considered tufa sites with strong chronological attribution based on combined proxies (Fig. 1).

\subsection{Tufa development over the Holocene}

The extended period of development of each of the 66 reviewed sites is shown in Fig. 1. These chronological attributions are generally based on palaeontological data (mainly pollen and molluscs) and thus discussed by authors in terms of chronozones (i.e. Preboreal, Boreal, Atlantic etc. periods) and/or Holocene subseries (Early, Middle or Late Holocene). These chronologies are here reported respectively senso (Mangerud et al., 1974) calibrated by (Walanus and Nalepka, 2010) and senso (Walker et al., 2012, 2019); ages are thus expressed here in calibrated years BP (Fig. 1). As a relative dating approach, biostratigraphy intrinsically involves uncertainties in terms of 'absolute' ages; 500yrs-intervals are thus considered in this review. Exceptions were made at the major chronological boundaries (i.e. Pleistocene (Tardiglacial)/Holocene, Early/Middle and Middle/Late Holocene boundaries) where those intervals are according to the formal subdivision dates from the International Commission on Stratigraphy (respectively 11.7, 8.2 and 4.2 ka cal. BP (Head and Gibbard, 2015; Walker et al., 2019; Walker et al., 2012).

At most sites, tufa development ceased between 2.5 at $5.5 \mathrm{ka}$ cal. BP, after the Atlantic optimum (Fig. 1). Fig. 4 shows the evolution of the number of sites precipitating tufa along the Holocene. While only a few sites are assigned to the Late Glacial, their number rapidly increased during the Early Holocene to a maximum at 7-7.5 ka cal. BP (50 sites; Fig. 1). The number of tufa sites then progressively decreased but more than a third of inventoried tufa still developed during the Late Holocene. The number of tufa sites even slightly increased again during the Subatlantic (ca. 1.5-2 ka cal. BP). This first look at the Holocene time distribution of European tufas thus indicates that part of them seems affected by a 'late-Holocene decline' but the phenomenon appears less marked and less systematic than previously described.

As suggested in previous publication, the size (Baker and Simms, 1998) and geomorphological position/type (Alexandrowicz et al., 2016; Dobrowolski et al., 2002; Ollivier et al., 2006) of tufa deposits may have induced them to be differently affected by a lateHolocene decline; reviewed data are thus further discussed regarding those assumptions.

\subsubsection{Effect of size}

The spatial extension (surface area) of reviewed tufas is not systematically provided by authors and apparently only mentioned when deposits are exceptionally large: 36 sites are reported as larger than $1000 \mathrm{~m}^{2}$, one site is 'small' (Loschour, Luxembourg), while no information is available for the 29 others (Fig. 1). Contrary to Baker and Simms (1998) who observed, in the UK, a decline in the deposition of large tufas $\left(>1000 \mathrm{~m}^{2}\right)$ as opposed to small sites $\left(<1000 \mathrm{~m}^{2}\right)$, no relationship between size and a cease in deposition during the Late-Holocene is demonstrated in this review of European tufas.

The height (or depth) of tufas is systematically shown in papers as their stratigraphy is almost always presented. This review thus also considers high (i.e. thicker than $10 \mathrm{~m})$ versus thin $(<10 \mathrm{~m}$ thick) deposits (Fig. 1). While thicker deposits, as there are likely to correspond to longer and/or more detailed records, could have been more attractive when looking for palaeoenvironmental information, they are not the most studied: 27 of the 66 tufa sites (i.e. 39 tufa thinner than $10 \mathrm{~m}$ ). Actually, the thickest tufas do not systematically cover the whole Holocene and conversely, the longer records are observed in 'thin' deposits (Fig. 1). As for the surface area, the height of tufas and so, their precipitation rate, do not show any relationship with their stop or continuation during the LateHolocene.

\subsubsection{Effect of geomorphological position and resulting type of tufa}

Many studies (including in this review) have shown the diversity of tufas and the wide lateral variability of facies within a single deposit, which both have induced difficulties in classifying them for decades and the development of complex nomenclatures (Ford and Pedley, 1996; Pedley, 1990, 2009; Pentecost and Viles, 1994). A review by Capezzuoli et al. (2014) attempted to simplify these classifications of tufas generally based on depositional geometry, details within stratigraphy and petrology (e.g. perched springline, cascade, fluvial, lacustrine, paludal) into three groups based on the physico-chemical and biological context of deposition resulting from the distance from the water spring(s): 1) resurgence (or proximal) environments, including e.g. mound spring and spring-fed mire or perched-springline tufas (Pedley, 1990; Pedley et al., 2003), where $\mathrm{CO}_{2}$-rich groundwater oversaturated in calcium ions degases as it flows away from the spring(s), increasing calcite precipitation also due to biological processes (linked to cyanobacteria, algae, vegetation, etc.); 2) intermediate environments, i.e. fluvial, including small cascades and barrages (Pedley, 1990), where calcite precipitation is mainly induced by cyanobacteria, algae and aquatic vegetation as water becomes undersaturated; and finally, 3) distal environments, where tufa deposition 
SITE CHARACTERISATION

RADIOCARBON DATING (ka uncal. BP)

\begin{tabular}{|c|c|c|}
\hline Site name & ö & Type \\
\hline $\begin{array}{l}\text { St Magdalena } \\
\text { Buzen }\end{array}$ & $\begin{array}{ll}A T \\
\text { BE }\end{array}$ & fluvial \\
\hline $\begin{array}{l}\text { Buzenol } \\
\text { Loschbour }\end{array}$ & $\mathrm{BE}$ & $\begin{array}{l}\text { Spring fed } \\
\text { Fluvial }\end{array}$ \\
\hline Val valley & ES & Fluvial barrage \\
\hline Varangu & EE & Lacustrine \\
\hline Trzebienice & PL & \\
\hline $\begin{array}{l}\text { Bezymiannoe } \\
\text { Wateringsbury }\end{array}$ & & $\begin{array}{l}\text { Lacustrine } \\
\text { Spring-fed calcareous swamn }\end{array}$ \\
\hline $\begin{array}{l}\text { Wateringsbury } \\
\text { Caerwys }\end{array}$ & $\begin{array}{l}G B \\
G B\end{array}$ & $\begin{array}{l}\text { Spring-fed calcareous swamp } \\
\text { Fluvial barrage }\end{array}$ \\
\hline Clénay (Norges valley) & $F R$ & fluvial \\
\hline $\begin{array}{l}\begin{array}{l}\text { Paestum } \\
\text { Bad Laer }\end{array} \\
\text { (a) }\end{array}$ & ${ }_{\text {GE }}^{\text {IT }}$ & $\begin{array}{l}\text { Lacustrine / palustrine } \\
\text { Spring fed }\end{array}$ \\
\hline $\begin{array}{l}\text { Rerzusnia } \\
\text { Rzerser }\end{array}$ & PL & \\
\hline $\begin{array}{l}\text { Zawadónka } \\
\text { Vierset-Barse (Houyoux valle }\end{array}$ & $\begin{aligned} P L & \\
P B E & \end{aligned}$ & $\begin{array}{l}\text { Calcareous mire } \\
\text { LLacustrine and fluvial }\end{array}$ \\
\hline & PL & $\begin{array}{l}\text { Lacastrine and tivvilal } \\
\text { Spring fed }\end{array}$ \\
\hline Villiers-Devant-Orval & BE & Fluvial barrage \\
\hline Raclawka & $\mathrm{PL}$ & \\
\hline Orval Abbaye & BE & Fluvio-palustre \\
\hline $\begin{array}{l}\text { Daours } \\
\text { Annevoie-Rouillon }\end{array}$ & $\begin{array}{l}F R \\
\mathrm{BE}\end{array}$ & $\begin{array}{l}\text { Fluvial barrage } \\
\text { Fuvial barrage }\end{array}$ \\
\hline $\begin{array}{l}\text { Annevole-kooumion } \\
\text { Ociemny stream }\end{array}$ & $\begin{array}{l}\mathrm{BE} \\
\mathrm{PL}\end{array}$ & Fluvial barrage with lacustrine areas \\
\hline Saint-Germain-le-Vasson & $\mathrm{FR}$ & Fluvio-palustrine \\
\hline Saspowska valley & $\mathrm{PL}$ & Fluvial barrage and cascade \\
\hline Sieradowice & PL & Fluvial barrage / lacustrine \\
\hline $\begin{array}{l}\text { Teklits } \\
\text { Okono }\end{array}$ & BY & $\begin{array}{l}\text { Lacustrine } \\
\text { Lacustrine }\end{array}$ \\
\hline Alport (Lathkill valley) & GB & $\begin{array}{l}\text { Lacusialine } \\
\text { Fluviage }\end{array}$ \\
\hline Saint-Antonin & FR & Fluvial barrage near springs \\
\hline Queiles valley & ES & Fluvial barrage \\
\hline La Vis & $F R$ & \\
\hline Vauvenargues & FR & Perched springs \\
\hline $\begin{array}{l}\text { Purón valley } \\
\text { Ptich }\end{array}$ & $\begin{array}{l}\text { ES } \\
\text { BY }\end{array}$ & $\begin{array}{l}\text { Fluvial barrage } \\
\text { Fluvial barrage }\end{array}$ \\
\hline Sedanillo valley & ES & Fluvial barrage and cascade \\
\hline Molinar valley & ES & Fluvial barrage \\
\hline Alcaraz & ES & Fluvial barrage / fluvial \\
\hline Hrhov & sk & Perched-springline \\
\hline & SK & Fluvial barrage and cascadde \\
\hline $\begin{array}{l}\text { Tubilla del aqua } \\
\text { Saint Gilhem le Désert }\end{array}$ & $\begin{array}{l}E S \\
F R f\end{array}$ & $\begin{array}{l}\text { Fuvial barrage and cascade } \\
\text { fluvial }\end{array}$ \\
\hline Triponzo & & Fluvial barrage \\
\hline Treignes & $\mathrm{BE}$ & Fluvio-palustrine \\
\hline Svaty Jan pod Skalou & $\mathrm{cz}$ & Perched-springline \\
\hline $\begin{array}{l}\text { Komarów } \\
\text { Jouques }\end{array}$ & $\begin{array}{l}\mathrm{PL} \\
\mathrm{FR}\end{array}$ & $\begin{array}{l}\text { Calcareous spring-fen } \\
\text { Fluvio-palustrine }\end{array}$ \\
\hline Meyrargues (Grand Vallat) & FR & Spring-fed fluvial \\
\hline Pont-de-Joux & & Lacustrine behind a fluvial barrage \\
\hline Hamblain-les-Prés & FR & $\begin{array}{l}\text { Lacustrine } \\
\text { Le }\end{array}$ \\
\hline St Momelin & $F R$ & Lacustrine \\
\hline Guînes & FR & Lacustrine \\
\hline Dolina Eliaszówki Nature Res & & Spring fed \\
\hline $\begin{array}{l}\text { Plaśnie } \\
\text { Skotsicki troam }\end{array}$ & PL L & Lacustrine \\
\hline $\begin{array}{l}\text { Skotnicki stream } \\
\text { TYka }\end{array}$ & $P L$ & Lacustrine \\
\hline $\begin{array}{l}\text { Tylka } \\
\text { Homole Gorge }\end{array}$ & & $\begin{array}{l}\text { Lacustrine } \\
\text { Lacustrine }\end{array}$ \\
\hline $\begin{array}{l}\text { Homole Gorge } \\
\text { Laguna Redondilla }\end{array}$ & ES L & $\begin{array}{l}\text { Lacusustrine } \\
\text { Lacuine }\end{array}$ \\
\hline & & Soligenous mire \\
\hline Plitvice & $\pi i n$ & $\begin{array}{l}\text { Lacustrine barrages } \\
\text { Larnes }\end{array}$ \\
\hline Krka & HR L & Lacustrine barrages \\
\hline Ethe (Las & BE & $\begin{array}{l}\text { Spring fed } \\
\text { Perched-springline }\end{array}$ \\
\hline jirendall & LU & $\begin{array}{l}\text { Perched-springline } \\
\text { Lacustrine }\end{array}$ \\
\hline $\begin{array}{l}\text { Lake Ántu Sinijärry } \\
\text { Mituchoce }\end{array}$ & EE L & $\begin{array}{l}\text { Lacusustrine } \\
\text { Calcareous spring-fen }\end{array}$ \\
\hline $\begin{array}{l}\text { Mituchovce } \\
\text { Inchrory }\end{array}$ & $\begin{array}{l}S K \\
G B\end{array}$ & $\begin{array}{l}\text { Calcareous spring-ten } \\
\text { Spring fed }\end{array}$ \\
\hline Krzywi & & Soligenous mire \\
\hline
\end{tabular}

TOTAL SITES
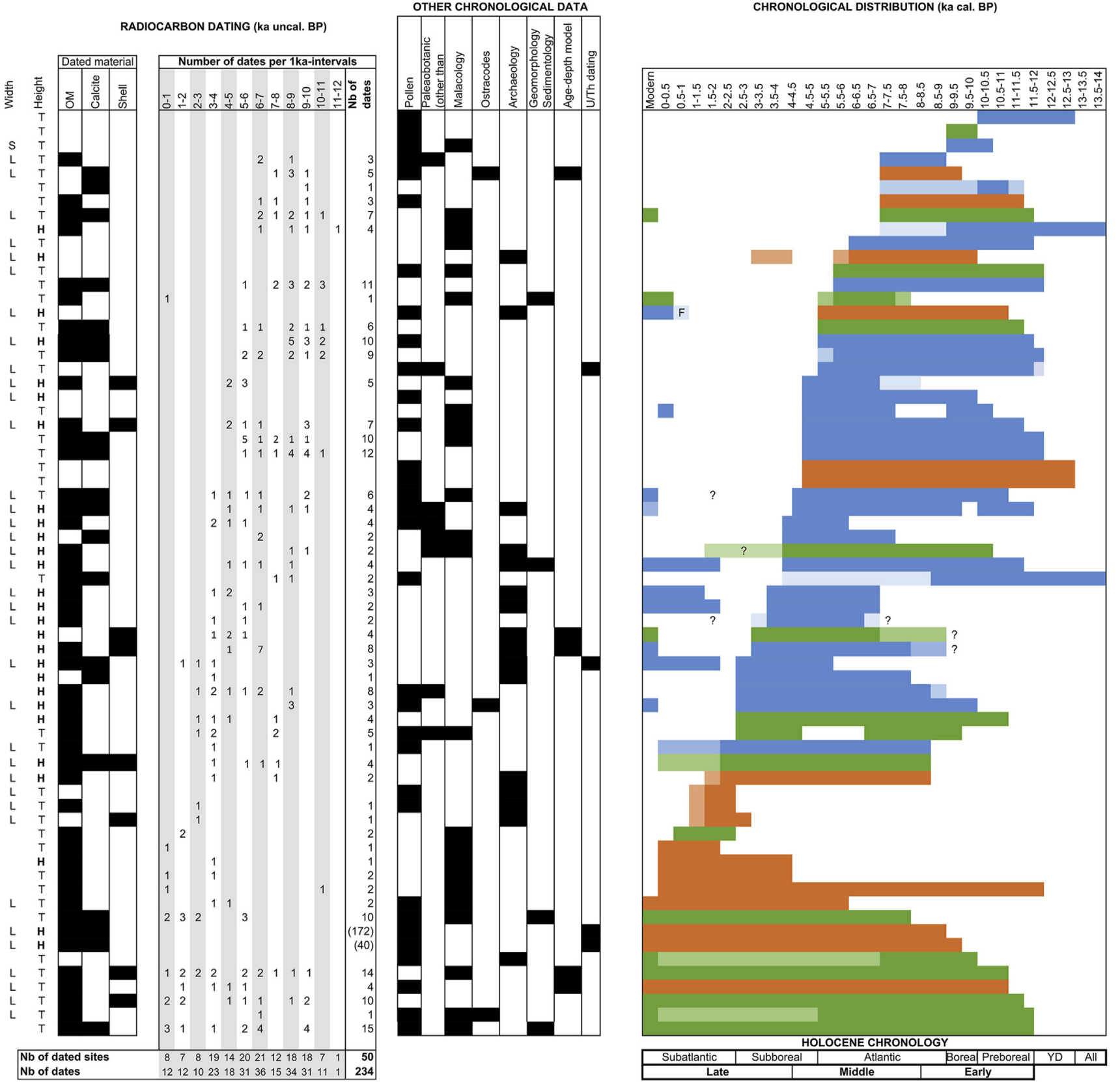

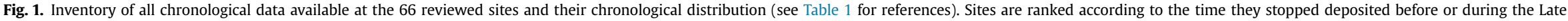
Holocene. At some sites, a second phase of deposition is observed during the Subatlantic after a hiatus of 500 years or more; the date they stopped precipitating before the hiatus is then considered to rank them. Site characterisation

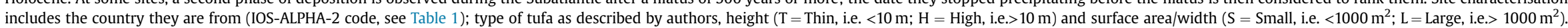



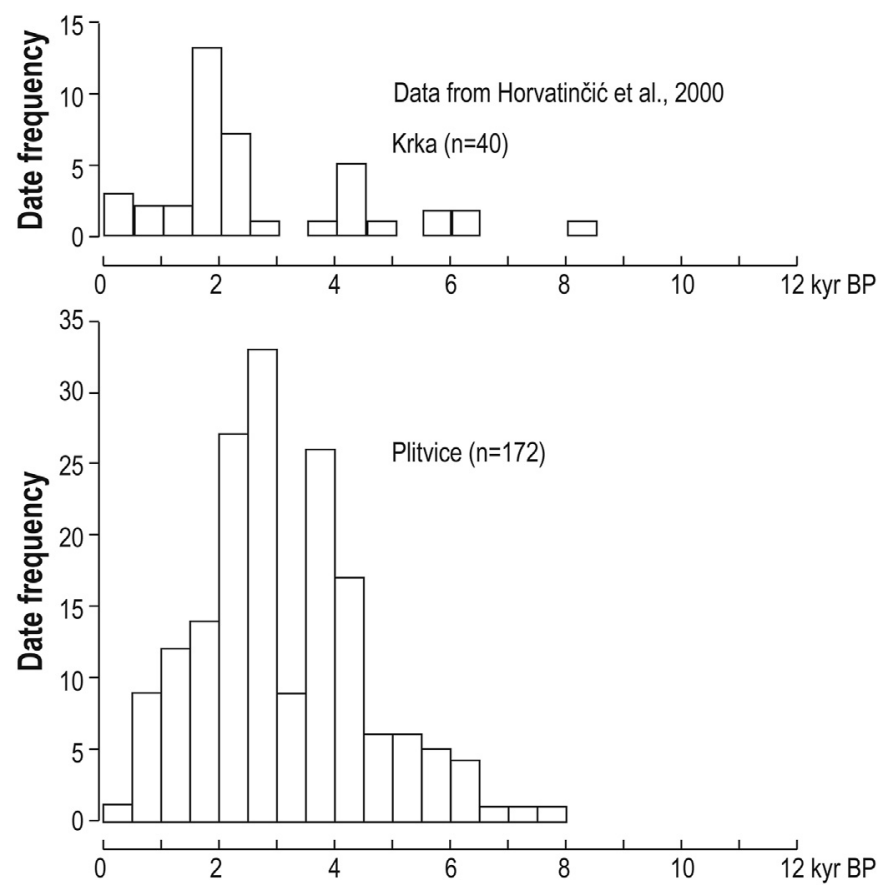

Fig. 2. Frequency distribution per 500 yrs-intervals of radiocarbon dates from Krka and Plitvice tufas (Croatia) after Horvatinčić et al. (2000).


Fig. 3. Frequency distribution per 1 ka-intervals of radiocarbon dates from European tufas after Pentecost (2005) compared to both date and dated site frequencies from this review (scales are the same).

becomes scarce and generally form intercalated lenses/units within ( silico) clastic sediments (e.g. braided stream; Pedley, 1990).

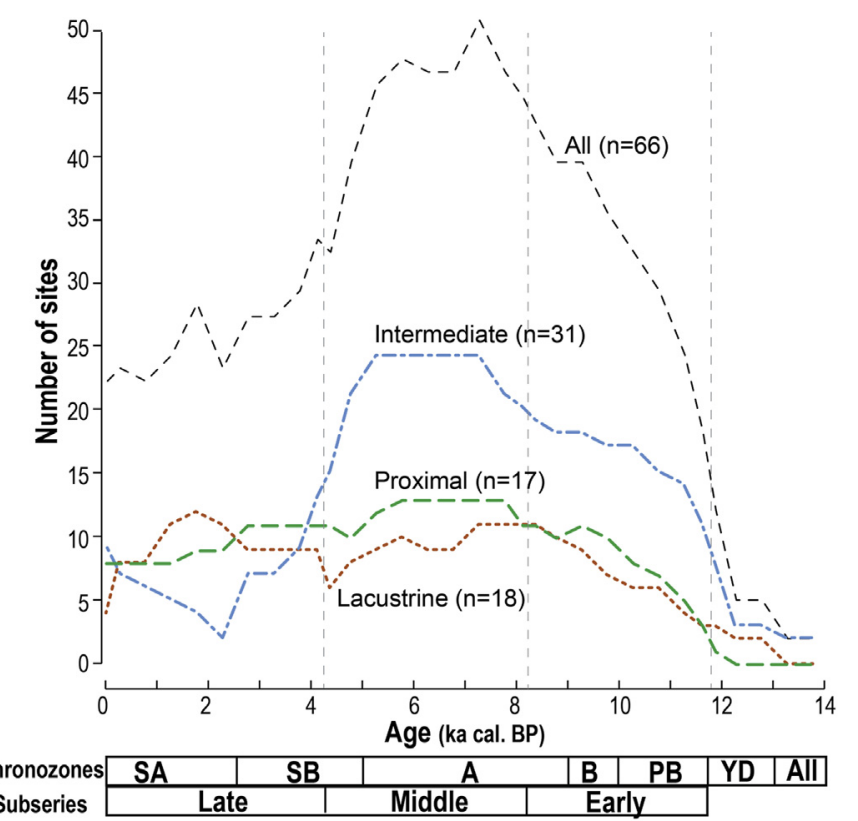

Fig. 4. Evolution of the number of all, intermediate, proximal and lacustrine tufas during the Tardiglacial and the Holocene (from 14 ka cal. BP).

In this new review, proximal (spring/resurgence) and intermediate (fluvial) tufas have been distinguished. As they do not result in (nearly) continuous large and high tufa accumulations, the third context of tufa deposition (distal) is usually not considered regarding the Holocene development of tufa and their environmental record; none of the reviewed tufa can be attached to this group. Besides, lacustrine tufas are here discriminated as they may develop in the three above described environments but due to their low energy context, they are less related to degassing (in proximal environment) but might be affected by evaporation processes (intermediate to distal environment (Capezzuoli et al., 2014; Pedley et al., 2000; Pedley et al., 2003). The three types of tufas (proximal, intermediate, and lacustrine) are shown by different colours in Fig. 1 and the evolution of their number reported in Fig. 4.

Among the 66 reviewed sites, 31 tufas are intermediate (fluvial) deposits, 18 are lacustrine tufas and 17 are, perched-springline or spring-fed mire, proximal deposits.

The ten sites that did not stop developing during the Holocene are all proximal or lacustrine tufas while all intermediate (fluvial) deposits are affected by a decline (Fig. 1). After a maximum between 7.5 and $5 \mathrm{ka}$ cal. BP, the number of intermediate deposits rapidly decreases after the Atlantic and during the Late Holocene (from 24 sites during the Atlantic to only 2 fluvial tufas reported at $2-2.5 \mathrm{ka}$ cal. BP) while the number of lacustrine and especially of proximal deposits remains relatively constant (respectively 6-12 and 5-9 tufa sites since the Atlantic; Fig. 4). In detail, we may notice that a stop in the deposition of some lacustrine and proximal deposits is observed but, if these tufas thus seem affected by a decline, the phenomenon does not appear systematic contrary to fluvial deposits (Fig. 1). These observations strongly demonstrate that the general notion of a late-Holocene tufa decline in Europe is a reality only for intermediate (fluvial) tufas.

\section{Mechanisms of a tufa decline: climate or human impact?}

In their 1993 paper, Goudie et al. listed 26 hypotheses to explain a decline in tufa deposition; they are summarised in Table 2. Their diversity reflects the complexity of the mechanisms involved in 
Table 2

Possible mechanisms explaining a late-Holocene decline in tufa deposition (after Goudie et al., 1993).

\begin{tabular}{|c|c|c|c|c|c|}
\hline & & $\begin{array}{l}\text { Possible opposite } \\
\text { effects }\end{array}$ & $\begin{array}{l}\text { Climatic or } \\
\text { Anthropic }\end{array}$ & $\begin{array}{l}\text { Local/regional } \\
\text { effect }\end{array}$ & $\begin{array}{l}\text { Type of tufa likely } \\
\text { to be affected }\end{array}$ \\
\hline \multicolumn{6}{|c|}{ Changes in water discharge } \\
\hline 1 & $\begin{array}{l}\text { diminution due to climatic changes (i.e. reduction of } \\
\text { rainfall) }\end{array}$ & yes & $\mathrm{C}$ & $\mathrm{R}$ & All \\
\hline 2 & $\begin{array}{l}\text { diminution due to anthropogenic impact (e.g. pumping of } \\
\text { aquifers, diversion of channels, etc.) }\end{array}$ & & A & $\mathrm{R} / \mathrm{L}$ & All but especially Interm. \\
\hline 3 & increase due to climatic changes (i.e. increasing rainfall) & & $\mathrm{C}$ & $\mathrm{R}$ & All \\
\hline 4 & $\begin{array}{l}\text { increase due to anthropogenic (e.g. deforestation, } \\
\text { urbanisation, ditching) }\end{array}$ & & A & $\mathrm{L}$ & Interm. \\
\hline 5 & increasing variability of discharge (i.e. flooding) & & $\mathrm{C} / \mathrm{A}$ & $\mathrm{R} / \mathrm{L}$ & Interm. \\
\hline \multicolumn{6}{|c|}{ Changes in water chemistry } \\
\hline 6 & increased stream turbidity due to soil erosion & & $A(C)$ & $\mathrm{R}$ & Interm. \\
\hline $7-8$ & $\begin{array}{l}\text { changes in the } \mathrm{CaCO} 3 \text { content of soils due to weathering and } \\
\text { cumulative post-glacial leaching }\end{array}$ & & $\mathrm{C} / \mathrm{A}$ & $\mathrm{R}$ & All \\
\hline 9 & $\begin{array}{l}\text { changes in thickness and cover of soil due to erosion } \\
\text { (leading to changes in soil CO2 level) }\end{array}$ & & $\mathrm{C} / \mathrm{A}$ & $\mathrm{R}$ & All \\
\hline 10 & nutrient release (e.g. nitrates) due to deforestation & & $A(C)$ & $\mathrm{L}(\mathrm{R})$ & All \\
\hline $11-13$ & $\begin{array}{l}\text { water pollution from fertilisers, sewage and industrial } \\
\text { effluents or acid deposition }\end{array}$ & yes & A & $\mathrm{L}(\mathrm{R})$ & All \\
\hline 12 & Reduced $\mathrm{CO} 2$ flux due to deforestation & & $A(C)$ & $\mathrm{L}(\mathrm{R})$ & All \\
\hline \multicolumn{6}{|c|}{ Changes in catchment environment } \\
\hline $14-15$ & $\begin{array}{l}\text { deforestation leading to changes in shade and temperature } \\
\text { of the streamwater }\end{array}$ & yes & $A(C)$ & $\mathrm{L}$ & Prox. and Interm. \\
\hline 16 & $\begin{array}{l}\text { introduction of domestic stock causing trampling and } \\
\text { intensive eutrophication }\end{array}$ & & A & $\mathrm{L}$ & Prox. and Interm. \\
\hline 17 & $\begin{array}{l}\text { removal of trees from catchment which reduces the supply } \\
\text { of fallen trunks and branches at the basis for many barrage } \\
\text { tufas }\end{array}$ & & A & $\mathrm{L}$ & All \\
\hline 18 & decreasing temperature and rates of evaporation & & $\mathrm{C}$ & $\mathrm{R}$ & All \\
\hline 19 & $\begin{array}{l}\text { deforestation/devegetation of floodplain making them } \\
\text { more susceptible to channel migration and erosion }\end{array}$ & & A & $\mathrm{L}(\mathrm{R})$ & Interm. \\
\hline 20 & changes in the water base level (e.g. sea-level changes) & & $\mathrm{C}$ & $\mathrm{R}$ & Interm. and Lac. \\
\hline 21 & self limiting tufa deposition (tufa growth damming itself) & & - & $\mathrm{L}$ & All \\
\hline 22 & quarrying of existing tufa & & A & $\mathrm{L}$ & All \\
\hline 23 & building of dams, weirs, mills or bridges & yes & A & $\mathrm{L}(\mathrm{R})$ & All but especially Interm. (and Lac.) \\
\hline 24 & storm damage/catastrophic collapse of unstable tufa & yes & - & $\mathrm{L}$ & All but especially Interm. (and Lac.) \\
\hline 25 & tectonic activity (+landsliding) & yes & - & $\mathrm{L}$ & All but especially Interm. (and Lac.) \\
\hline 26 & draining and channeling of marshland & & A & $\mathrm{L}$ & Interm. \\
\hline
\end{tabular}

tufa deposition/erosion and their sensitivity to numerous parameters including water and atmospheric temperature, water and soil chemistry, water dynamic and landscape changes. This complexity also results in possible opposite effects of a single mechanism as they might co-depend on other mechanisms or involved parameters (Table 2; Goudie et al., 1993). Most of those mechanisms are either climatically or anthropogenically induced.

Climate changes such as rainfall increase or decrease (mechanisms 1 and 3 ) and decreasing atmospheric temperature (mechanism 18) are likely to have regionally impacted the development of all types of tufas (Table 2). Calcareous tufas indeed require warm and wet conditions and are thus characteristic of Interglacial periods (Ambert, 1981; Ford and Pedley, 1996; Pentecost, 2005). The maximal number of tufa deposits during the Holocene climatic optimum, the Atlantic period (Fig. 4), shows this strong link between tufa development and climate (Dramis et al., 2014; MartínAlgarra et al., 2003; Vaudour, 1986a; Vaudour, 1994; Weisrock, 1986). Other hypotheses related to climate changes have been proposed to explain this relationship such as variations in the atmospheric $\mathrm{CO}_{2}$ concentrations controlling the rate of tufa precipitation or the role of groundwater temperature on calcium carbonate dissolution within the aquifer (Dramis et al., 1999; Griffiths and Pedley, 1995).

According to those assumptions, a decline in tufa development following the optimum is expected. However, as previously demonstrated, such a decline does not systematically affect all types of tufas as proximal and lacustrine deposits are still well represented during the Subboreal and Subatlantic periods (Fig. 4).
Besides, the sharp decrease in the number of intermediate (fluvial) deposits by the start of the Subatlantic period, resulting in a total termination in tufa precipitation at most sites (Fig. 1), seems too important to be driven by climatic changes only (Pedley, 2009; Taylor et al., 1998). Additionally, comparisons can be made with older, chronologically well-constrained, Pleistocene tufas: for instance, at Caours (Eemien, MIS 5e) and La Celle (MIS 11) in Northern France, the most intensive tufa deposition actually occurred after the climatic optimum, while both temperature and rainfall amount (recorded by tufa calcite stable isotopes) declined (Antoine et al., 2006; Dabkowski et al., 2012, 2016; Limondin Lozouet et al., 2006). In this context of non- (or less-) humanimpacted deposits, the effect of moderate climate changes on tufa development thus appears limited. Those observations suggest, as debated for decades by many authors, that the Holocene decline in tufa development might be mostly driven by human activity (e.g. (González-Amuchastegui and Serrano, 2015a; GonzálezAmuchastegui and Serrano, 2015b; Gradziński et al., 2017; Nicod, 2010; Taylor et al., 1998; Vaudour, 1986b; Vaudour, 1994).

Anthropogenic modifications of landscapes or pollution can have affected tufa development either at a regional scale or near the altered area (local effect; Table 2). Deforestation is the human activity that results in the greatest number of possible side effects on tufa development through various mechanisms (Table 2; Goudie et al., 1993; Nicol-Pichard, 1986). First, deforestation has a strong impact on (ground) water chemistry: the induced increase in runoff contributes to soil erosion and leaching that, in turn, induce changes in soil $\mathrm{CaCO}_{3}$ and $\mathrm{CO}_{2}$ contents (mechanisms 7-9). Parallel, 
tree removal may lead to increasing nitrates in water while soil $\mathrm{CO}_{2}$ flux decreases because of the reduction of root respiration and leaf fall (mechanisms 10 and 12). Changes in the water composition are likely to have regionally impacted the development of tufa deposits of all types (Table 2). However, deforestation may also have local but strong impacts on the flood plain in terms of shade and temperature conditions (mechanisms 14-15), supply of material initiating barrages (mechanism 17) and erosion processes, which preferentially affect fluvial tufa deposits (Nicod, 2010): increasing runoff is likely to lead to greater erosion of soils providing detrital material into streams (increasing turbidity, mechanism 6) and the erosion of the tufa deposits themselves (mechanisms 4 and 5).

Channel and water management (mechanisms 2, 4, 23 and 26) is another strong contributor to tufa decline, specifically in the areas favoured by human settlements, i.e. in fluvial environments. Finally, pollution caused by human activity (fertilisers, industrial effluents, eutrophication due to introduction of domestic stock, etc.; mechanisms 11-13 and 16) can strongly impact tufa development at local to regional scales and especially fluvial tufa development as inputs concentrate in stream water (Casanova, 1986; Nicod, 2010); Table 2).

This overview emphasises that fluvial tufa deposits are more exposed to anthropogenic changes especially related to agricultural practices and land management than other types of tufas. Additionally, several authors have noticed the chronological concordance between the start of the European tufa decline (from ca. $5 \mathrm{ka}$ cal. BP; Fig. 4) and the onset of the Bronze Age during which forest clearance practises, pastoralism and river management rapidly increased (Alexandrowicz and Skoczylas, 2017; GonzálezAmuchastegui and Serrano, 2015a; Lippmann and Vernet, 1986; Taylor et al., 1998; Vaudour, 1986b, 1994). A Late-Holocene tufa decline is thus observed in intermediate (fluvial) deposits in Europe because of increasing human impact on landscapes, which more systematically impacts them compared to other types of tufa.

\section{Conclusions}

This review of the time distribution of 66 European tufas has considered all chronological data available at each site. Radiocarbon date (or dated site) frequency does not appear as a relevant mean to discuss the presence/absence of tufa deposits during the Holocene due to numerous biases in the sample availability and their stratigraphic distribution. Combining biochronological data to absolute dates, a general trend to a reduced number of tufa deposits after a maximum at $7-8 \mathrm{ka}$ cal. BP is observed. If no relationship is shown between size (neither the surface area nor the height) and the time distribution of tufa, strong differences have been evidenced according to their geomorphological position: only intermediate tufas, precipitating in fluvial environment, are systematically affected by a late-Holocene decline, from the end of the Atlantic period (ca. $5 \mathrm{ka}$ cal. BP). No significant trend is observed in the number of lacustrine and proximal (spring) tufas during the Holocene. Consequently, the late-Holocene tufa decline should not be considered as a paradigm any more.

Regarding the possible causes of the decline, increasing human impact on landscapes with the development of agricultural and land management practices from the Bronze Age would explain both the timing of this decline and that it preferentially (and systematically) affects fluvial deposits compared to the other tufas. Lacustrine and proximal deposits may obviously be also affected at some sites by local settlements but no pattern is shown at the European scale. These assumptions involve that Holocene calcareous tufas are promising archives to disentangle the combined effects of climate and anthropisation at different scales of space and time.
Finally, we have to notice that this review has considered the decline of Holocene tufas on a presence/absence basis in the continuity of previous investigations (Goudie et al., 1993; Pentecost, 1995) but changes in the precipitation rate or facies could be further discussed as well (Dobrowolski et al., 2002).

\section{Acknowledgements}

I am grateful to Nicole Limondin-Lozouet, Salomé Granai and all colleagues who encouraged me to write this article and gave feedback on the discussion. I thank Michał Gradziński and two anonymous reviewers for their helpful comments on the manuscript.

\section{References}

Alexandrowicz, S.W., 1996. Malacofauna and age of the landslide in the Homole Gorge. Chronmy Przyr. Ojczysta 52, 45-54.

Alexandrowicz, S.W., Bałaga, K., Dobrowolski, R., 1994. Etapy rozwoju torfowiska kopułowego Krzywice w okolicach Chełma Lubelskiego. Zesz. Naukowe AGH Geol. 20 (3), 259-273.

Alexandrowicz, W.P., 1983. Malacofauna of Holocne calcareous sediments of the Cracow upland. Acta Geol. Pol. 33 (1-4), 117-158.

Alexandrowicz, W.P., 2013. Malacological sequence from profile of calcareous tufa in Groń (Podhale Basin, southern Poland) as an indicator of the Late Glacial/Holocene boundary. Quat. Int. 293, 196-206.

Alexandrowicz, W.P., Skoczylas, S., 2017. Molluscan assemblages from calcareous tufa in the Skalski stream valley (Peininy Mountains, Southern Poland) and their implication for reconstruction of natural and anthropogenic environmental changes. Carpath. J. Environ. Sci. 12 (2), 583-594.

Alexandrowicz, W.P., Szymanek, M., Rybska, E., 2016. Molluscan assemblages from Holocene calcareous tufa and their significance for palaeoenvironmental reconstructions. A study in the Pieniny Mountains (Carpathians, Southern Poland). Carpath. J. Environ. Sci. 11 (1), 37-54.

Ali, A., Guendon, J.-L., Terral, J.-F., Roiron, P., 2003. Les systèmes travertineux holocènes et les paléopaysages méditerranéens et subalpins (France) : une analyse géobotanique séquentielle à haute résolution spatiale. Géogr. Phys. Quaternaire 57 (2-3), 219-235.

Amato, V., Di Paola, G., Rosskpf, C.M., Avagliano, G., Cipriani, M., Cinque, A., Pontrandolfo, A., Santoriello, A., 2009. Geomorphology and geoarchaeology of the Paestum area: modifications of the physical environment in historical times. Méditerranée 112, 129-135.

Ambert, P., 1981. Thème V : chronologie et synchronisme paléoclimatique. Mém. l'Assoc. Fr. Karstol. 3, 201-206.

Ambert, P., 1986. Les tufs holocènes du plateau du Larzac : données actuelles. Méditerranée 61-65.

Andrews, J.E., 2006. Palaeoclimatic records from stable isotopes in riverine tufas: synthesis and review. Earth Sci. Rev. 75 (1-4), 85-104.

Andrews, J.E., Pedley, H.M., Dennis, P.F., 1994. Stable isotope record of palaeoclimatic change in a British Holocene tufa. Holocene 4 (4), 349-355.

Andrews, J.E., Pedley, M., Dennis, P.F., 2000. Palaeoenvironmental records in Holocene Spanish tufas: a stable isotope approach in search of reliable climatic archives. Sedimentology 47 (5), 961-978.

Antoine, P., Limondin-Lozouet, N., Chaussé, C., Lautridou, J.P., Pastre, J.F., Auguste, P. Bahain, J.J., Falguères, C., Galehb, B, 2007. Pleistocene fluvial terraces from northern France (Seine, Yonne, Somme): synthesis, and new results from interglacial deposits. Quat. Sci. Rev. 26 (22-24), 2701-2723.

Antoine, P., Limondin Lozouet, N., Auguste, P., Locht, J.L., Ghaleb, B., Reyss, J.L., Escudé, E., Carbonel, P., Mercier, N., Bahain, J.J., Falguères, C., Voinchet, P, 2006. Le tuf de Caours (Somme, France) : Mise en évidence d'une séquence éémienne et d'un site paléolithique associé. Quaternaire 17 (4), 281-320.

Antoine, P., Munaut, A.-V., Limondin Lozouet, N., Ponel, P., Fagnart, J.-P., 2002. Réponse des milieux de fond de valle aux variations climatiques (Tardiglaciaire et début Holocène), d'après les données du bassin de la Selle (Nord de la France). Processus et bilan sédimentaire. In: Bravard, J.P., Magny, M. (Eds.), Les fleuves ont une histoires, paléoenvironnements des réivières et des lacs français depuis 15000 ans. Errance, Paris, pp. 15-27.

Aranbarri, J., Bartolomé, M., Alcolea, M., Sancho, C., Celant, A., GonzálezSampériz, P., Arenas, C., Magri, D., Rodríguez-Lázaro, J, 2016. Palaeobotanica insights from early-mid holocene fluvial tufas in the Moncayo natural Park (Iberian Range, NE Spain): regional correlations and biogeographic implications. Rev. Palaeobot. Palynol. 234 (Suppl. C), 31-43.

Baker, A., Simms, M.J., 1998. Active deposition of calcareous tufa in Wessex, UK, and its implications for the 'late-Holocene tufa decline'. Holocene 8 (3), 359-365.

Bögli, A., 1980. Karst Hydrology and Physical Speleology. Springer-Verlag, Berlin, p. 284.

Bonifay, E., 1986. Origine et âge des formations travertineuses de la Vallée de l'Huveaune entre Roquevaire et Auriol. Méditerranée, pp. 101-104.

Brou, L., Court-Picon, M., Dabkowski, J., Naton, H.-G., 2014-2015. Le gisement mésolithique d'Heffingen-Loschbour (G.-D. de Luxembourg). Bilan des études 
paléoenvironnementales depuis 2003. Bull. Soc. Préhist. Luxemb. 36-37, 69-96.

Capezzuoli, E., Gandin, A., Pedley, M., 2014. Decoding tufa and travertin (fresh water carbonates) in the sedimentary record: the state of the art. Sedimentology 61, $1-21$.

Casanova Jean, 1986. Perte de pouvoir encroûtant des cyanophycées constructrices de travertins liée à la pollution : exemple de l'Huveaune (Var). Méditerranée 57, 179. Travertins LS et évolution des paysages holocènes dons le domaine méditerranéen, troisième série.

Clair, A., Doret, G., Puisségur, J.-J., 1972. Un exemple de sédimentation quaternaire dans les vallées de moyenne importance en domaine paléarctique. Quaternaire $101-124$.

Coûteaux, M., 1969. Formation et chronologie palynologique des tufs calcaires du Luxembourg belgo-grand-ducal. Quaternaire 179-206.

Dabkowski, J., 2014. High potential of calcareous tufas for integrative multidisciplinary studies and prospects for archaeology in Europe. J. Archaeol. Sci. 52, $72-83$.

Dabkowski, J., Brou, L., Naton, H.-G., 2015. New stratigraphic and geochemical data on the Holocene environment and climate from a tufa deposit at Direndall (Mamer Valley, Luxembourg). Holocene 25 (7), 1153-1164.

Dabkowski, J., Frodlová, J., Hájek, M., Hájková, P., Petr, L., Fiorillo, D., Dudová, L., Horsák, M., 2018. A complete Holocene climate and environment record for the Western Carpathians (Slovakia) derived from a tufa deposit. Holocene 29 (3), 493-504.

Dabkowski, J., Limondin-Lozouet, N., Antoine, P., Andrews, J., Marca-Bell, A., Robert, V., 2012. Climatic variations in MIS 11 recorded by stable isotopes and trace elements in a French tufa (La Celle, Seine Valley). J. Quat. Sci. 27 (8), 790-799.

Dabkowski, J., Limondin Lozouet, N., Andrews, J., Marca-Bell, A., Antoine, P., 2016 Climatic and environmental dynamic during the Eemian recorded in a Northern France tufa (Caours, Somme Basin). Comparison with regional records. Quaternaire 27 (3), 249-261.

Dabkowski, J., Limondin Lozouet, N., Antoine, P., Marca-Bell, A., Andrews, J., 2011. Enregistrement des variations climatiques au cours des interglaciaires d'après l'étude des isotopes stables de la calcite de tufs calcaires pléistocènes du nord de la France : exemple des séquences de Caours (SIM 5e ; Somme) et de La Celle-Sur-Seine (SIM 11 ; Seine-et-Marne). Ouaternaire 22 (4), 275-283.

Del Giovine, A., 1986. Les travertins holocènes de la cascade de Vauvenargues (Bouches-du-Rhône). Méditerranée 81-91.

Dobrowolski, R., Bałaga, K., Buczek, A., Alexandrowicz, W.P., Mazurek, M., Hałas, S., Piotrowska, N., 2016. Multi-proxy evidence of Holocene climate variability in Volhynia Upland (SE Poland) recorded in spring-fed fen deposits from the Komarów site. Holocene 26 (9), 1406-1425.

Dobrowolski, R., Durakiewicz, T., Pazdur, A., 2002. Calcareous tufas in the soligenous mires of eastern Poland as an indicator of the Holocene climatic changes. Acta Geol. Pol. 52 (1), 63-73.

Dobrowolski, R., Hajdas, I., Melke, J., Alexandrowicz, W.P., 2005. Chronostratigraphy of calcareous mire sediments at Zawadówka (Eastern Poland) and their use in palaeogeographical reconstruction. Geochronometria 24, 69-79.

Dramis, F., Fubelli, G., Calderoni, G., Esu, D., 2014. Holocene aggradation/degradation phases of tufa dams in northern Ethiopia and central Italy: a palaeoclimatic comparison between East Africa and Mediterranean Europe. Z. Geomorphol. 58 (4), 419-434.

Dramis, F., Materazzi, M., Cilla, G., 1999. Influence of climatic changes on freshwater travertine deposition: a new hypothesis. Phys. Chem. Earth A Solid Earth Geod. 24 (10), 893-897.

Emontspohl, A.-F., 1994. Enregistrement pollinique du début du Weichsélien et de l'Holocène à Fampoux, vallée de la Scarpe (Nord, France). Quaternaire 35-40.

Evans, J.G., 1972. Land Snails in Archeology. Seminar press, London and New York, p. 436.

Faulkner, T., Brazier, V., 2016. Tufa deposits at Inchrory and Glen Suie, Moray, Scotland. Cave Karst Sci. 43 (1), 17-20.

Ford, T.D., Pedley, H.M., 1996. A review of tufa and travertine deposits of the world. Earth Sci. Rev. 41 (3), 117-175.

Franco, B., Houbrechts, G., Van Campehout, J., Hallot, E., Petit, F., 2008. Etude géomorphologique des barrages de travertins du Hoyoux. Bull. Soc. Géogr. Liège 50, 45-56.

Fritz, A., 1976. Pollenananalytische Untersuchungung des Kalktuffes von St. Magdalena bei Feistritz im Gailtal (Karnten). Carinth. II 166 (86), 163-172.

Fubelli, G., Dramis, F., Calderoni, G., Cilla, G., Materazzi, M., Mazzini, I., Soligo, M., 2013. Holocene aggradation/erosion of a tufa dam at Triponzo (Central Italy) Geogr. Fis. Din. Quaternaria 36 (1), 139-149.

Garnett, E.R., Andrews, J.E., Preece, R.C., Dennis, P.F., 2006. Late-glacial and Early Holocene climate and environment from stable isotopes in Welsh tufa. Quaternaire 17 (2), 31-42.

Garnett, E.R., Gilmour, M.A., Rowe, P.J., Andrews, J.E., Preece, R.C., 2004. 230Th/234U dating of Holocene tufas: possibilities and problems. Quat. Sci. Rev. 23 (7-8), 947-958.

Gob, A., Heim, J., Spier, F., Ziesaire, P., 1984. Nouvelles recherches à l'abri du Loschbour près de Reuland (G.-D. Lux.). Bull. Soc. Préhist. Luxemb. 6, 87-99.

González-Amuchastegui, M.J., Serrano, E., 2015a. Holocene Tufa changes in response to human impact on environments: Upper Ebro Basin. Northern Spain. Z. Geomorphol. Suppl. Iss. 59 (2), 199-223.

González-Amuchastegui, M.J., Serrano, E., 2015b. Tufa buildups, landscape evolution and human impact during the Holocene in the Upper Ebro Basin. Quat. Int. 364,
54-64.

González-Pellejero, R., 1986. Dinamica de un espacio natural: los cañones calcareos del Ebro (Burgos). Eria 10, 5-86.

Goudie, A.S., Viles, H.A., Pentecost, A., 1993. The late-Holocene tufa decline in Europe. Holocene 3 (2), 181-186.

Gradziński, M., Hercman, H., Jaśkiewicz, M., Szczurek, S., 2013. Holocene tufa in the Slovak Karst: facies, sedimentary environments and depositional history, 57 (4), 2013.

Gradziński, M., Hercman, H., Rizzi, M., Stachowicz-Rybka, R., Stworzewicz, E., 2017. Sedimentation of Holocene tufa influenced by the Neolithic man: an example from the Sąspowska Valley (southern Poland). Quat. Int. 437, 71-83.

Gradziński, M., Szulc, J., Motyka, J., Stworzewicz, E., Tyc, A., 2001. Travertine mound and cave in a village of Laski, Silesian-Cracow upland. Ann. Soc. Geol. Pol. 71, $115-123$.

Griffiths, H.I., Pedley, H.M., 1995. Did changes in late Last Glacial and early Holocene atmospheric $\mathrm{CO} 2$ concentrations control rates of tufa precipitation? Holocene 5 (2), 238-242.

Guendon, J.L., Ali, A., Roiron, P., Terral, J.F., Anna, A.d., Diaz del Olmo, F., Baena Escudero, R, 2003. Les travertins de Saint-Antonin: séquence géobotanique et climato-anthropique holocène (Bouches-du-Rhône, France). Karstologia 1-14.

Guendon, J.-L., Vaudour, J., 1981. Les "tufs" holocènes de Saint-Antonin-sur-Bayon (B-du-R) : aspects petrographique et signification paleogéographique. Mém. l'Assoc. Fr. Karstol. 3, 89-100.

Gueurts, M.-A., 1976. Genèse et stratigraphie des travertins de fond de vallée en Belgique, vol. 16. Acta Geographica Lovaniensis, Louvain, p. 104.

Hájek, M., Dudová, L., Hájková, P., Roleček, J., Moutelíková, J., Jamrichová, E., Horsák, M., 2016. Contrasting Holocene environmental histories may explain patterns of species richness and rarity in a Central European landscape. Quat. Sci. Rev. 133, 48-61.

Head, M.J., Gibbard, P.L., 2015. Formal subdivision of the quaternary system/period: past, present, and future. Quat. Int. 383, 4-35.

Hiltermann, H., 1977. Die Sinterkalke (travertine) von Bad laer am Teutoberger Wald. Nat. Heim. 37, 77-80.

Horvatinčić, N., Čalić, R., Geyh, M.A., 2000. Interglacial growth of tufa in Croatia. Quat. Res. 53 (2), 185-195.

Janssen, A., Swennen, R., 1997. Petrography and geochemistry of the travertine deposit at Treignes (S. Belgium). Bull. Soc. Belge Géol. 106, 97-115.

Janssen, A., Swennen, R., 1999. Organic components and diagenetic products in the travertine deposit at Villiers-devant-orval. Geol. Belg. 2 (3-4), 197-212.

Kalm, V., Sohar, K., 2010. Oxygen isotope fractionation in three freshwater ostracod species from Early Holocene lacustrine tufa in northern Estonia. J. Paleolimnol. 43, 815-828.

Laumets, L., Kalm, V., Poska, A., Kele, S., Lasberg, K., Amon, L., 2014. Paleoclmiate inferred from $\delta^{18} \mathrm{O}$ and palaeobotanical indicators in freshwater tufa of Lake Äntu Sinijärv, Estonia. J. Paleolimnol. 51, 99-111.

Limondin-Lozouet, N., Preece, R.C., 2004. Molluscan successions from the Holocene tufa of St Germain-le-Vasson, Normandy (France) and their biogeographical significance. J. Quat. Sci. 19 (1), 55-71.

Limondin-Lozouet, N., Preece, R.C., 2014. Quaternary perspectives on the diversity of land snail assemblages from northwestern Europe. J. Molluscan Stud. 80 (3), $224-237$.

Limondin-Lozouet, N., Preece, R.C., Antoine, P., 2013. The Holocene tufa at Daours (Somme Valley, northern France): Malacological succession and palaeohydrological implications. Boreas 42 (3), 650-663.

Limondin Lozouet, N., Antoine, P., Auguste, P., Bahain, J.J., Carbonel, P., Chaussé, C., Connet, N., Dupéron, J., Dupéron, M., Falgueres, C., Freytet, P., Ghaleb, B., JollySaad, M.C., Lhomme, V., Lozouet, P., Mercier, N., Pastre, J.F., Voinchet, P., 2006. Le tuf calcaire de La Celle-sur-Seine (Seine-et-Marne): nouvelles données sur un site clé du stade 11 dans le nord de la France. Quaternaire 17 (2), 5-29.

Limondin Lozouet, N., Gauthier, A., Preece, R.C., 2005. Enregistrement des biocènoses de la première moitié de l'Holocène en contexte tufacé à SaintGermain-le-Vasson (Calvados). Quaternaire 16 (4), 255-271.

Lippmann, M., Vernet, J.P., 1986. Les travertins holocènes de Paestum (Italie méridionale). Méditerranée 45-51.

Ložek, V., 2009. Malakostratigrafie Holocenního Pěnovce U Stankovan Na Severním Slovensku, Geoscience Research Reports for 2008. Czech Geological survey, Praha, pp. 229-232.

Magnin, F., Guendon, J.-L., Quinif, Y., Roiron, P., Thinon, M., 1990. Datations isotopiques et études des paléoenvironnements de la formations de travertins de la Papeterie Vasino (Meyrargues, Bouches-du-Rhône, France). Mise en évidence de deux périodes de réchauffement durant le Riss. C. R. l'Acad. des Siences Paris 310 (II), 1285-1292.

Magnin, F., Thinon, M., 1988. Les travertins holocènes de Vauvenargues et de SaintAntonin (Bouches-du-Rhöne): nouvelles données sur les paléoenvrionnements (malacologie, anthracologie). In: Vaudour, J. (Ed.), Travaux 1988, n XVII, Les édifices travertineux et l'histoire de environnement dans le Midi de la France. U.A. 903 CNRS et A.T.P. - PIREN (Aix-en-Provence).

Makhnach, N., Zernitskaja, V., Kolosov, I., Simakova, G., 2004. Stable oxygen and carbon isotopes in Late Glacial-Holocene freshwater carbonates from Belarus and their palaeoclimatic implications. Palaeogeogr. Palaeoclimatol. Palaeoecol. $209(1-4), 73-101$.

Mangerud, J., Andersen, S.T., Berglund, B.E., Donner, J.J., 1974. Quaternary stratigraphy of Norden, a proposal for terminology and classification. Boreas 3 (3), 109-126.

Martín-Algarra, A., Martín-Martín, M., Andreo, B., Julià, R., González-Gómez, C., 
2003. Sedimentary patterns in perched spring travertines near Granada (Spain) as indicators of the paleohydrological and paleoclimatological evolution of a karst massif. Sediment. Geol. 161 (3), 217-228.

Meyrick, R.A., 2000. Holocene molluscan faunal history and environmental change from a tufa at Direndall, Luxembourg. Bull. Soc. Préhist. Luxemb. 22, 55-75.

Mullenders, W., Duvigneaud, J., Coremans, M., 1963. Analyse Pollinique De DéPóTs De Tuf Calcaire Et De Tourbe à Treignes (Belgique). Grana Palynol. 4 (3), 439-448.

Nicod, J., 2010. Barrage de tufs calcaires et cascades dans le Centre-Var : rapport avec les eaux des sources karstique, historique et déclin actuel. Physio-Géo 4, 42-67.

Nicol-Pichard, S., 1986. Analyse pollinique de sédiments associés à des travertins, Jouques (Bouches-du-Rhône). Méditerranée 21-24.

Ollivier, V., Guendon, J.-L., Ali, A., Roiron, P., Ambert, P., 2006. Evolution postglaciaire des environnements travertineux provençaus et alpins : nouveau cadre chronologique, faciès et dynamiques morphosédimentaires. Quaternaire 17 (2), $51-67$.

Ortiz, J.E., Torres, T., Delgado, A., Reyes, E., Díaz-Bautista, A., 2009. A review of the Tagus river tufa deposits (central Spain): age and palaeoenvironmental record. Quat. Sci. Rev. 28 (9-10), 947-963.

Paepe, R., 1965. Découverte d'un foyer dans les travertins d'Annevoie-Rouillon. Bull. Soc. Belge Géol. 74, 305-315.

Paepe, R., Souchez, R., Peeters, G., Kugler, M., 1970. Le barrage de travertin de la vallée du Williers (sondages de Villers-devant-Orval), 1970/01 - 051. Geological Survey of Belgium.

Pastre, J.F., Limondin-Lozouet, N., Gebhardt, A., Leroyer, C., Fontugne, M., Krier, V., 2001. Lateglacial and holocene fluvial records from central part of the Paris basin (France). In: Maddy, D., Macklin, M.G., Woodward, J.C. (Eds.), River Basin Sediment Systems: Archives of Environmental Change. Balkema, Leiden, pp. $357-373$.

Pazdur, A., Dobrowolski, R., Durakiewicz, T., Mohanti, M., Piotrowska, N., Das, S., 2002. Radiocarbon time scale for deposition of Holocene calcareous tufa from Poland and India (Orissa). Geochronometria 21, 85-96.

Pazdur, A., Pazdur, M.F., 1986. 14C dating of calcareous tufa from different environments. Radiocarbon 28 (2A), 534-538.

Pazdur, A., Pazdur, M.F., 1990. Further investigations on $14 \mathrm{C}$ dating of calcareous tufa. Radiocarbon 32 (1), 17-22.

Pazdur, A., Pazdur, M.F., Szulc, J., 1988. Radiocarbon dating of holocene calcareous tufa in southern Poland. Radiocarbon 30 (2), 133-152.

Pazzaglia, F., Barchi, M.R., Buratti, N., Cherin, M., Pandolfi, L., Ricci, M., 2013. Pleistocene calcareous tufa from the Ellera basin (Umbria, central Italy) as a key for an integrated paleoenvironmental and tectonic reconstruction. Quat. Int. 292, 59-70.

Pedley, H.M., 1990. Classification and environmental models of cool freshwater tufas. Sediment. Geol. 68 (1), 143-154.

Pedley, M., 2009. Tufas and travertines of the Mediterranean region: a testing ground for freshwater carbonate concepts and developments. Sedimentology 56 (1), 221-246.

Pedley, M., et al., 1996. Does climate control the morphological fabric of freshwater carbonates? A comparative study of Holocene barrage tufas from Spain and Britain. Palaeogeogr. Palaeoclimatol. Palaeoecol. 121 (3), 239-257.

Pedley, M., Hill, I., Denton, P., Brasington, J., 2000. Three-dimensional modelling of a Holocene tufa system in the Lathkill Valley, north Derbyshire, using groundpenetrating radar. Sedimentology 47 (3), 721-737.

Pedley, M., Martín, J.A.G., Delgado, S.O., García Del Cura, M.Á., 2003. Sedimentology of Quaternary perched springline and paludal tufas: criteria for recognition, with examples from Guadalajara Province, Spain. Sedimentology 50 (1), 23-44.

Pentecost, A., 1993. British travertines: a review. Proc. Geologists' Assoc. 104 (1), 23-39.

Pentecost, A., 1995. The quaternary travertine deposits of Europe and Asia Minor. Quat. Sci. Rev. 14 (10), 1005-1028.

Pentecost, A., 2005. Travertine. Springer-Verlag, Berlin Heidelberg, p. 445.

Pentecost, A., Viles, H., 1994. A review and Reassessment of travertine classification. Géogr. Phys. Quaternaire 48 (3), 305-314.

Preece, R.C., Bennett, K.D., Robinson, J.E., 1984. The biostratigraphy of an early Flandrian tufa at Inchrory, Glen Avon, Banffshire. Scott. J. Geol. 20 (2), 143-159.
Quinif, Y., 2012. U/Th dating of the Annevoie-Rouillon travertines. Geol. Belg. 15 (3), $165-168$.

Ricci, M., Bertini, A., Capezzuoli, E., Horvatinčić, N., Andrews, J.E., Fauquette, S., Fedi, M., 2015. Palynological investigation of a Late Quaternary calcareous tufa and travertine deposit: the case study of Bagnoli in the Valdelsa Basin (Tuscany, central Italy). Rev. Palaeobot. Palynol. 218, 184-197.

Roglic, J., 1977. Les lacs de Plitvice (Yougoslavie). Norois 305-318.

Sohar, K., Meidla, T., 2010. Changes in the Early Holocene lacustrine environment inferred from the subfossil ostracod record in the Varangu section, northern Estonia. Est. J. Earth Sci. 59 (3), 195-206.

Sommé, J., 2006. Tufs calcaires holocènes récents dans le nord de la France. Quaternaire 17 (2), 43-49.

Souchez, R., Paepe, R., 1972. Radiocarbon ages and valley floor evolution in South Belgium. Bull. Soc. Belge Géol. 81 (3-4), 221-225.

Srdoč, D., Obelić, B., Horvatinčić, N., Culiberg, M., Šercelj, A., 1985. Radiocarbon dating and pollen analyses of two peat bogs in the Plitvice National Park. Acta Bot. Croat. 44 (1), 41-46.

Srdoč, D., Obelic, B., Horvatinčic, N., Sliepčevic, A., 1980. Radiocarbon dating of calcareous tufa: how reliable data can we expect? Radiocarbon 22 (3), $858-862$.

Srdoč, D., Osmond, J.K., Horvatinčić, N., Dabous, A.A., Obelić, B., 1994. Radiocarbon et Uranium-series dating of the Plitvice lakes travertines. Radiocarbon 36 (2) 203-219.

Starkel, L., Michczyńska, D., Krąpiec, M., Margielewski, W., Nalepka, D., Pazdur, A., 2013. Progress in the holocene chrono-climatostratigraphy of Polish territory. Geochronometria 40 (1), 1-51.

Stirn, A., 1964. Kalktuffvorkommen und Kalktufftypen der Schwäbischen Alb. Abhandlungen zur Karst- und Höhlenkunde. Reihe E (Botanik) 1, 1-92.

Szulc, J., 1983. Geneza i klasyfikacja wapiennych osadów martwicowych. Przeglad Geol. 31 (4), 231-236.

Taylor, D.M., Pedley, H.M., Davies, P., Wright, M.W., 1998. Pollen and mollusc records for environmental change in central Spain during the mid- and late Holocene. Holocene 8 (5), 605-612.

Thorpe, P.M., Otlet, R.L., Sweeting, M.M., 1980. Hydrological implications from 14C profiling of UK tufa. Radiocarbon 22 (3), 897-908.

Van Der Woude, J., Roeleveld, W., 1985. Paleoecological evolution of an interior coastal zone : the case of the Northern France coastal plain (Evolution paléoécologique d'une zone côtière interne : le cas de la plaine maritime du Nord de la France). Quaternaire, pp. 31-39.

Vaudour, J., 1986a. Introduction à l'étude des édifices travertineux holocènes. Méditerranée 3-10.

Vaudour, J., 1986b. Travertins holocènes et pression anthropique. Méditerranée 168-173.

Vaudour, J., 1994. Évolution holocène des travertins de vallée dans le Midi méditéranéen français. Géogr. Phys. Quaternaire 48 (3), 315-326.

Vinken, R., 1968. Zur Entstehung und Altersstellung der Travertine, limnischen Sedimente und fluviatilen Terrassen im Gebiet der Mittleren Nera und des Corno (Umbrien, Mittelitalien). E\&G Qua. Sci. J. 19 (1), 5-30.

Walanus, A., Nalepka, D., 2010. Calibration of Mangerud's boundaries. Radiocarbon 52 (4), 1639-1644.

Walker, M., Head, M.J., Lowe, I., Berkelhammer, M., BjÖrck, S., Cheng, H., Cwynar, L.C., Fisher, D., Gkinis, V., Long, A., Newnham, R., Rasmussen, S.O., Weiss, H., 2019. Subdividing the Holocene Series/Epoch: formalization of stages/ages and subseries/subepochs, and designation of GSSPs and auxiliary stratotypes. J. Quat. Sci. 34 (3), 173-186.

Walker, M.J.C., Berkelhammer, M., Björck, S., Cwynar, L.C., Fisher, D.A., Long, A.J., Lowe, J.J., Newnham, R.M., Rasmussen, S.O., Weiss, H., 2012. Formal subdivision of the holocene series/epoch: a discussion paper by a working group of INTIMATE (Integration of ice-core, marine and terrestrial records) and the Subcommission on quaternary stratigraphy (international Commission on stratigraphy). J. Quat. Sci. 27 (7), 649-659.

Weisrock, A., 1986. Variations climatiques et périodes de sédimentation carbonatée à l'holocène. L'âge des dépôts. Méditerranée 165-167.

Žák, K., Ložek, V., Kadlec, J., Hladíková, J., Cílek, V., 2002. Climate-induced changes in holocene calcareous tufa formations, Bohemian karst, Czech Republic. Quat. Int. 91 (1), 137-152. 